\title{
PROPAGANDA AND INFORMATION IN INTERNATIONAL AFFAIRS
}

\author{
CHARLES A. SIEPMANN†
}

History is a record of aspirations expressed in deeds and in words. In words men have found both inspiration for their deeds and a clearer definition of the things they seek. "We hold these truths...." "Liberté, égalité, fraternité," "Workers of the World, unite!"-in these and like phrases men have sought finality of purpose, a clear, unquestionable goal to offset the haunting sense of the precariousness of "truth" and "certainty." Words are thus signposts of aspiration pointing toward a destination.

Words have once more been found to crystallize aspiration. The new signpost, erected by the signatories of 44 nations, reads thus: "The governments of the states parties to this constitution on behalf of their peoples declare that since wars begin in the minds of men, it is in the minds of men that the defenses of peace must be constructed; that ignorance of each other's ways and lives has been a common cause, throughout the history of mankind, of that suspicion and mistrust between the peoples of the world through which their differences have all too often broken into war. ... For these reasons, the States, parties to this Constitution, ... . are agreed and determined to develop and to increase the means of communication between their peoples and to employ these means for the purposes of mutual understanding and a truer and more perfect knowledge of each other's lives. . . ."1

Here is fresh insight into the causes of war and a new determination to build defenses of peace in the minds of men. New means thereto are sought which, until now, were wholly visionary. The new hope rests on the opportunity which modern technology makes possible. We are entering an era in which, for the first time in history, nations can communicate with one another, if they so will. Sight and hearing are now co-extensive with the globe. Before we examine how best to use the devices now available for conquering space, it may be well to review briefly what these devices are and how they have revolutionized the scope and pattern of communications.

\section{Communication's Golden Age}

Radio, television, films, facsimile: these are but a few of the key words unlocking doors which open on breath-taking vistas of oppor-

† Chairman, Dept. of Communications in Education, and Professor of Education, New York University; policy consultant, Domestic Radio Bureau, Office of Facts and Figures; later deputy to Assistant Director, O.W.I.; special consultant to Director of Information, UNRRA, 1945-6. Publications include: Radio in Wartime, 1942; Radio's Second Chance, 1946.

1. Conslitution of the United Nations Educational Scientific and Cultural Organization, Der't of State, Conference Ser. No. 80 (1946) 13-4. 
tunity. Given the fillip of wartime necessity, incredible advances in all these fields have been made. Advances in wireless transmission include speeds of $\$ 00$ words a minute. By war's end more than 360 radio transmitters in more than fifty countries were sending more than 2,000 words a minute round the world in over forty languages. It is now possible, mechanically at least, for any publication to receive the equivalent of a hundred thousand words of foreign news daily. TYe have prospect of television broadcasts from the stratosphere, of broadcasting systems using airplanes as transmitter sites. Four-color facsimile makes it possible to transmit photographs and whole pages of books and periodicals in any language. "TVithin a matter of years, perhaps months, it will be possible for a film or periodical originating at one point to be distributed and exhibited throughout the globe in two or three days. Whole pages of magazines can now be taken off on cellophane mats, light as feathers, and flown to printing plants over the world, thus making possible the simultaneous publication on five continents of a complete magazine forty-eight hours after the material has been written. . ." 2 The walkie-talkie is just around the corner. We have the tools. Can we use them to good purpose? Does more communication mean greater understanding, or will it obscure truth and confirm prejudice?

No country has given more thought to the problem of international communications than the United States. Two documents are indispensable to any student of the subject-a memorandum on "The Postwar International Information Program of the United States" prepared in 1945 for the State Department by Dr. Arthur IY. Macilahon, and "Peoples Speaking to Peoples", the Leigh-White report published in 1946 by the Commission on Freedom of the Press. Both documents are primarily concerned with the means of expediting and extending the transmission of useful knowledge between peoples and with the concomitant problem of how such transmission can most effectively be organized. Both documents take account of the phenomenal development of international communication resulting from the war. These wartime activities provide a convenient starting point for study of the uncharted future.

\section{Wartine Developaients: Profit and Loss}

The effects of the wartime use of all the media of communication, as they bear on the use of these media for the advancement of peace, are at once positive and negative. The rapid technological advances realized have already been alluded to. We are now in communication's golden age. But other significant gains must also be recorded. From a national point of view, the most important perhaps is the dominant

2. White and Leigh, Peoples Speaking to Peoples (1946) 10. 
position, relative to other nations, achieved in the communications field by the United States. We escaped in wartime from our backward place in the prewar race for the attention and interest of other peoples. Prior to the war, we could claim supremacy in the realm of films alone. In tele-communications, whether by cable or radio, in the export of books and magazines, in the use of short wave broadcasting, other countries were aheàd of us.

A further signal gain was the creation of a structure through which alone the rapid wartime advance in the projection of America across the globe was made possible. In the Office of War Information and the Office of Inter-American Affairs, we had agencies through which execution of an integrated plan was made possible and through which an understanding of America was disseminated to an unprecedented extent. More significant than the creation of a new structure was the realization of a new conception of the importance of communications in the creation of good will. In these agencies with which the radio and film industries and publishers were, to a varying extent, cooperatively associated, a new sense of responsibility was born and a salutary realization of the dangers, as well as of the advantages, inherent in the power of world-wide communication.

But while great gains were made, there were also setbacks. Perhaps the major obstacle to the constructive use of communications for peaceful purposes is a word-propaganda-which "stands like a great dragon folded in the gate to forbid all entrance." The occasion for the semantic decline and disrepute of this word is of the greatest social and historical interest, but its examination lies beyond the scope of this study. Suffice it here to say that as the result of war and despite our own adoption in propaganda of the so-called strategy of truth, a peculiar allergy exists among millions to communication between peoples. The cure of this allergy lies deeper than the severance of government from activity in the communications field. Private agencies are likewise suspect. The good manners of communication have been corrupted. The rapid dissolution of OWI and OIAA and the cool reception by the House of Representatives of the State Department's modest budget for the continuance of essential services in international communications both derive, in part at least, from the widespread allergy, particularly in the United States, to propaganda. Propaganda has likewise been used as the excuse for the withdrawal by the Associated Press and United Press of the continued use of their services by the State Department. The excuse hardly bears examination, but illustrates the extent of the prevalent allergy and the consequent sympathy which appeal to the menace of "propaganda" can arouse.

Associated with the fear of propaganda is a second negative consequence of wartime activities-the direct and indirect controls imposed within countries on access to information from abroad. In Germany, 
Japan and elsewhere death penalties were attached to listening to short wave radio. Indirect controls, such as the manufacture of radio sets without short wave facilities, "jamming," etc., are likevise symptoms of wartime nerves. The whole world has been affected with a fear, partly real, partly illusory. The best hope for world recovery from this sickness of suspicion is rapid restoration of the good manners of communication. But more, perhaps, is needed and it is at this point that the lawyer's help may first be looked for. To re-establish good manners of communication, some form of international convention may be necessary by means of which the evil and aggressive aspects of the use of propaganda are eliminated. One student of the problem suggests that as part of a general disarmament agreement, the following acts be defined as acts of psychological aggression and outlawed by all signatories: "(a) Discrediting, or attempting to discredit, the government of another signatory nation, especially among its own citizens; (b) dividing, or attempting to divide, the people of another signatory nation among themselves; (c) discrediting, or attempting to discredit, the structure and philosophy of government, or the social or economic way of life of the people of any other signatory nations; (d) stimulating, or attempting to stimulate, prejudice, hate and discrimination ... against any racial, social, economic, political or religious group anywhere in the world." 3 The necessity for agreement on such points is the measure of the decline in the use of international communications, largely resulting from Nazi philosophy and practice, which we have witnessed in the last ten years.

A serious negative effect, not of the war but of our peacetime reaction to it, is the rapid squandering since V-J Day of the resources and techniques so effectively developed during the war years for carrying information about ourselves to other peoples. Under the impulse of reconversion we have virtually destroyed the machinery by which the voice of America was carried to all corners of the earth. Nor has provision been made for any substitute machinery to take its place. As a result, in such fields as radio, films, books, and magazines, it seems we are about to revert to our laggard prewar pace toward the goal of understanding and approval of our way of life by others. This lapse would seem to be the consequence of our inability to adjust our thinking in a crucial context to the requirements of the modern world. We have acted as though our choice were between two irreconcilable alternatives-government control (in this case, of the media of communication) and unfettered private enterprise. The notion of a partnership and a working relation between government and private enterprise is at once so novel and so alien to our traditional patterns of thinling that we insist on an "either-or" decision in the matter and overlook

3. WaRburg, Untritten Treaty (1916) 157-8. 
the possibilities of compromise. New considerations of public interest have arisen which involve private industry (in the communication field as in many others) in the shouldering of responsibilities beyond those of profit making, and which imply a direct concern by govern. ment with the activities of private industry. Sooner or later, by means which cannot here be explored, we must exorcise from our thinking the curious notion that government is an inherent evil and a menace to a free society.

Against this brief background of wartime gains and losses, let us review the problems that face us in the peace. The broad objective is the progressive extension of rapid and cheap facilities for international communication designed to further understanding and to create good will. The twofold character of this objective needs to be borne steadily in mind. Mere extension of facilities is not in itself enough. The purpose for which they are employed is paramount. The problems to be solved can best be illustrated by a piecemeal analysis of the various media of communication which science and enterprise have made available.

\section{Tele-Communications and the Press}

Of over a billion adults in the world only about one in four can read more than a few words of his own tongue. In so far as we seek understanding through access to the printed word, increased literacy is thus a first condition of expanded influence. Here at the outset, then, we hit upon a pressing item for the agenda of the United Nations. Add to the problem of illiteracy the babel of languages throughout the world, and we hit upon a second item for an international agendaconsideration of joint action on the development of a common international language.

But while the influence of the press and the printed word generally is thus necessarily circumscribed, it cannot be precisely equated with illiteracy or even the circulation of newspapers. In what we call civilized countries, the prestige of the press is immense. Its comprehensive coverage of news and interests, its convenience as compared with radio, in that it can be read selectively and at the leisure and convenience of the reader, give it a unique significance. But, before a newspaper can be printed, it must receive material to print. Facilities for gathering and transmitting world news are, in the international sphere, the key to the future influence of the press and of the printed word. What is needed is ". . . the linking of all the habitable parts of the globe with abundant, cheap, significant, true information about the world from day to day." " Before the war only one twentieth of the globe had easy access to abundant and reliable world news. During the war British

4. WHITE AND LEIGE, op. cit. supra note 2, at 13. 
and American enterprise went far to populate these previously desert areas of information. Means of communication have been multiplied, making of cable networks an obsolescent channel of communication. Outstanding among innovations has been the development of "multiple address" press transmission by radio. By this means, news is sent on a wide beam to an area of several thousand square miles within which it can be picked up simultaneously by hundreds of contracting newspapers. Point-to-point radio and the rapid development of airline communications add to our modern resources for conquering space and time. The facilities are here, how can they be used to the best advantage?

The United States is virtually unique among the major nations in that its government, as of the moment, is not directly involved in the main business of furnishing tele-communication services. Here in America, nine companies, most of them competing for the same business, monopolize the field. The giants in this field of enterprise are the International Telephone and Telegraph Corporation, Western Union, Radio Corporation of America, American Telephone and Telegraph, and Press Wireless Incorporated. But since Pearl Harbor vast networks of communication have been developed by the U. S. Army and Navy. Details about them are still shrouded in mystery but it is at least known that their book value exceeds by a wide margin the total value of all the existing privately owned facilities. The taxpayer, or the citizen, thus has a double interest in the question of the future organization of our tele-communication system. He has a huge financial investment at stake and an even more precious investment in terms of the peace which the misuse of communications may well do much to wreck.

There has, for some time, been discussion of the desirability of a merger of the various private financial interests in this field. Multiple ownership and the interests of private investors in such obsolescent methods of communications as cables are said to impair efficiency and to retard reduction of rates. The government's vast wartime investment in communications networks gives it a legitimate interest in this field, but an even more urgent cause for government intervention is the crucial public interest in the good relations of this country with the rest of the world. Merger would seem to involve a choice between a government agency of a non-profit nature working in the public interest or a private corporation regulated by government both with respect to the use of the facilities and the rates to be charged, likewise in the public interest. The Commission on the Freedom of the Press recommends that all United States cable and radio telegraph companies be merged, voluntarily if possible, or, if necessary, by act of Congress and joined with government facilities not needed for direct military purposes. Their proposal provides for certain exemptions, notably for a 
single tele-communications corporation devoted to the transmission of press material and also, for the time being, for existing radio telephone facilities.

Whether such a domestic merger takes place or not, the time has clearly come for international review and agreement regarding effective and fair use of the now available facilities. Agreement between governments is now urgent on three main matters. First is the allocation of short wave frequencies to avoid interference between competing users of the channels of the air. Second is agreement on rates for commercial traffic running across national borders. And third is the need for countries like our own, without widespread colonial possessions, to secure relay stations on foreign territory in order to facilitate multipleaddress newscasting and perhaps voice broadcasting as well. The complexities of competing interests between governments and of the commercial interests of their nationals defy enumeration here. All one can do is to identify an area for negotiation and ultimate agreement. It would be disastrous if there should occur in the international field a confusion and a breakdown comparable to that which attended the development of broadcasting in this country until the aid of government was invoked by the competitors themselves in 1927.

However, even if we assume a satisfactory solution of problems respecting the actual transmission of sound and words, we are only at the beginning of our difficulties. There are many countries which do not allow foreign news agencies to sell directly to publications within their borders. "Official" intermediaries are interposed, through whom such services are channelled and by whom they may be tampered with. Again, there are countries from which foreign newspapers are banned. Countries within the Russian sphere of influence impose restrictions on news gathering which range from direct censorship to discrimination against persons whose interpretation of events is regarded as "disloyal."

Such problems cannot be solved by any verbal form of agreement relating to freedom of the press. The question is more complex, in. volving antithetical conceptions of what constitutes freedom. On the one hand, we have an interpretation of this concept as defined by Mr. Sumner Welles. " "There is every reason why such a charter should contain the specific stipulation that no nation may become a member of the new international organization unless it is able to demonstrate that by its constitution, or by its basic legislation, the citizens of such nation are granted as inalienable rights freedom of worship, of expression and of information." Compare this with the definition of "freedom" as given by a Russian writer. "In the Soviet Union only, where

5. Welles, Pillars of Human Rights (1944) 8 FREE WoRLD 219, 220.

6. Baltisky, Freedom of the Press, WAR AND tHE Workrng Class (Jan. 1, 1945) 8, 9, as reported in N. Y. Times, Jan. 7, 1945, §1, p. 15, col. 1, 3. 
all power is in the hands of the toilers of the cities and villages represented by Soviet deputies, a judicial right to issue their own newspapers and magazines is guaranteed by the supply of toilers and their organizations with paper, printing offices, buildings, communications and other commodities. Everything is guaranteed by the Soriet Constitution. Upon this foundation the exceedingly strong growth of the press became possible."

The reconciliation of such conflicting points of view cannot be looked for overnight. It would seem that it must be attacked piecemeal. Some measure of agreement has been reached already, and more may be looked for regarding free access to news by foreign correspondents. It can hardly be expected that consent will be forthcoming for the ideal sought for by MIr. Kent Cooper, "that "there should be an international understanding... that an individual granted a passport as a news correspondent . . . shall be afforded diplomatic immunities. . . ." Much, however, could meanwhile be done to allay suspicion by more rigid adherence to standards of responsibility and a more careful selection of the type of correspondent whom we send abroad. Irresponsibility of individual correspondents has done much to arouse resentment in the past and to undermine the confidence of other nations in our sincerity of purpose in voicing our concept of the principle of freedom of the press. The Commission on Freedom of the Press takes account of this possibility and puts forward a constructive proposal. "One way might be to tighten the foreign correspondents' corps; adopt a code of professional behavior and require all newsmen, ... to join the corps and observe the code. Appeals from decisions of a government could be taken by the whole corps rather than by an individual, either to the foreign diplomatic corps or to an appropriate unit of the United Nations Economic and Social Council." 8 With respect to censorship, it makes like constructive proposals. "A logical first step might be to press for a multilateral agreement pledging the signatories to keep newsmen informed of the rules by which they expect to operate and to abide by them. If such agreement could be reached, the climate might encourage a second and simultaneous step: agreement to limit censorship ... to the open deletion or suppression of dispatches in the presence of the writer. . . . At a favorable moment, Moscow might even subscribe to a third condition: right of appeal by the writer to the correspondents' corps and through it to the United Nations Economic and Social Council." 9

\section{Radio BROADCASTING}

Radio as a medium compares unfavorably with the press in that it holds the listener to a rigid timetable and a one-time hearing. Until

7. In an address reported in N. Y. Times, Jan. 22, 1945, p. 11, col. 2, 6.

8. WHTTE AND LEIGE, op. cit. supra note 2, at 68 .

9. Id. at 70 . 
international television becomes practicable, it likewise lacks the impact and emotional range of appeal of such a medium as the film in which sight and sound are combined. But from the standpoint of international relations it has one unique advantage. By broadcasting alone can the voice of one country be carried to another, regardless of the latter's government. Not even the most terroristic methods of control avail against the will of people to tune in what they want to hear. The death penalty in Japan and Germany scotched listening, but did not kill it. Indeed, prohibition created a morbid appetite which thousands risked death itself to satisfy, and gave an added (and fatal) currency to rumor. Broadcasting is our only assured channel of international communication.

Before the war, the United States was slow to realize radio's international potentialities. Countries like Great Britain, Holland, Belgium, and France, with possessions overseas, and countries like Germany, Italy and Russia, with ideologies to sell, were all ahead of us. In the United States, where radio's development was dependent on private enterprise, the lack of profitable markets for advertisers retarded the growth of international broadcasting.

The war changed all this. By V-E Day, OWI and OIAA between them spanned the globe and were communicating the American message in more than forty languages. Relay transmitters in Great Britain and Algiers and throughout the Far East speeded our message on its way. The voice of America became an instrument which generals in all theatres have fully recognized as having made a signal contribution to the enemy's defeat and to the adherence of our allies to the cause which we espoused.

But with peace came the passion for reconversion and the instinctive urge to return to normalcy. We were through with propaganda and also through with government control. While other countries have maintained, if not expanded, their wartime short wave radio activities, we have cut ours to the bone. The State Department in which, after the war, the remnant forces of a once great army were incorporated, has prepared a meager budget for the maintenance, through broadcasts and a modest film project, of an overseas information service about the United States. A sum of $\$ 19,000,000$, after long debate and much opposition in the House of Representatives, has at last been approved. This budget amounts to one fifth of one per cent of that asked for by the War and Navy Departments. It amounts to less than one quarter of the peak wartime information budget. We have here some measure of the significance attached by Congress to radio as a medium for the maintenance of good will and understanding in other countries.

The size of prospective audiences for short wave broadcasts cannot easily be determined. There is no up to date information on the 
number of short wave receivers in different countries. We lnow that reception difficulties intervene. We know, too, that reaction has set in after the war among listeners numbered in hundreds of thousands who during the war would seek to satisfy starved appetites at almost any price. But for all this, the unique attribute of broadcasting, its passage undeterred across all frontiers, assures it of a future. The wartime habit of tuning in to broadcasts from overseas is even now slowly reasserting itself. The audience of the State Department's curtailed services, drastically reduced in hours and in the languages employed, is still considerable. Correspondence in May, 1946 from Latin America, Europe, and the Far East exceeded two thousand letters. A half dozen countries in Europe, China and IForea continue to relay over their national transmitters some of the State Department programs which have survived the axe of reconversion. Thether such audiences increase in number depends in large part on what we do.

On present showing, it would appear that we will forego the advantage which we wrested tardily in the war years. Having created an extensive market, we are going to let the stalls stand bare of supplies. In South America, where in the Argentine alone there are $\$ 00,000$ sets equipped for short wave reception, where 32 per cent of the set owners listen regularly to short wave and where 31 per cent have listened to the United States, the listener is to be put on short rations. According to Assistant Secretary Benton, ". . . Our embassies are practically" unanimous on the importance of short wave broadcasting. Forty per cent of the areas of the world, our embassies report, have dissatisfaction, to some extent, with the signals. . . . But because it is the only medium that they can get directly from the United States, ... . broadcasting has a special and important place. . . . Thus Moscon: cables 'Radio is the only medium through which the United States of America can speak freely and directly to the Soriet people'." 10

To the observer, it would seem self-evident that if the defenses of peace are to be built in the minds of men, the unique potentialities of short wave radio should be exploited to the full. A reversal of our current policy is indicated; expansion rather than contraction of efforts to secure yet wider audiences is essential. As all too often happens, the primary objective, the responsible projection of America, is being subordinated to what should be a secondary consideration, namely, who shall undertake the task and foot the bill.

It is easy to see how this comes about. The radio industry, though before the war half-hearted in its international efforts and activities, sees in the continued use of governmental agencies for short wave broadcasting an indirect threat to free enterprise in the domestic radio

10. Hearings before Sub-commillee of the Committec on Appropriations, Housc of Representatives, Dep't of State Appropriation Bill for 1947, 79th Cong., 2d Sess. (1916) 492. 
market. Government control and direction of international broadcasting is, they fear, the first step toward government control of domestic radio. It is significant, however, that the industry does not come forward with any program of its own that measures up to the need of continuing to carry the voice of America to all parts of the world. The cost involved is considerable; the returns through advertising revenue are questionable. No doubt impressed by radio's powerful lobby in Washington, the MacMahon report proposes for the State Department only a modest subsidiary role. In this and indeed all fields of international communication, "The portrayal of the United States," it says, "must be accomplished substantially by the normal currents of private interchange. . . . The role of the government is important, but it is facilitative and supplementary." 11 In radio at least there seem to be good grounds for judging that such a supplementary role will fall far short of the potentialities of the medium and of the need for better information abroad about the United States.

The problem from the point of view of Congress, concerned at once to serve the national interest and to conserve the taxpayers' bankroll, is admittedly not easy. The returns on the investment are intangible. The good will and understanding to be derived from extensive short wave services are neither easily assessed nor to be looked for quickly. But if the defenses of peace are to be built in the minds of men, we must have faith. No such half measures as are indicated by the comparative statistics quoted above can be worthwhile. One particular problem affecting the future success of our efforts deserves special consideration.

It would appear on a priori grounds that short wave broadcasting is subject to one inexorable law. The audience for it is likely to be in inverse proportion to the success and popularity of the domestic broadcasting in the country in question. Here in America, for example, where audience satisfaction is high, it has been estimated that not more than one per cent of listeners tune in short wave broadcasts. But here, as all too often, statistics can be misleading. That one per cent represents upwards of a million listeners. The social scientist, if not the radio executive, is not likely to underestimate the potentialities of international understanding as these may be realized through a million minds. This seemingly inexorable law, moreover, can be circumvented. If we and other nations can agree to the inclusion on our domestic radio of regular, reciprocal, exchange programs, we can speed understanding on its way and feed internationalism into our own systems. The preparation of transcribed programs for such exchanges can do much to sidestep the present difficulty of fitting a program of

11. Macmagon, Postwar International Information Program of the United States (1945) xi. 
foreign origin into the domestic program schedule at a convenient hour. Whether or not our networks persist in their aversion to the use of transcribed programs, local stations can perhaps be called upon to use them. The establishment by UNESCO of continental librarics of transcribed programs serving the cause of international understanding might well facilitate and expedite the adoption of such a principle of mutual exchange.

\section{FILMS}

Perhaps no medium has greater potentialities in the communication of information and the creation of attitudes than the film. Until recently, its exploitation in the interests of profits has resulted in its restriction by and large to the field of entertainment and impressionist coverage of events through newsreels. Before the war there was some pioneer development, particularly in Britain, in documentary films, pointing the way to more varied and more fruitful uses of the medium. But lack of finances and, more particularly, lack of outlets for the distribution of such films limited the range of their acceptance. The enterprise of Hollywood resulted in its virtual dominance of the field throughout the world.

Hollywood pictures were seen by audiences in practically every country where moving picture theatres existed. It was not until the war broke out that we came to appreciate that the impressions of America registered abroad by films produced in Hollywood were not always of a kind to enhance our prestige or to register a true impression of our way of life. The foreign missions of the State Department then began to bring home to us some of the problems involved in the export of films conceived for our domestic audience. Thus, from Australia it was reported in 1944, "A country boy or girl could not be blamed for thinking that the majority of Americans are engaged in crime or frivolity." ${ }^{12}$ From Morocco, in the same year, came a similar report. "To any American who lived abroad before the present war it will be only too obvious that American pictures were of such a character as to convince foreigners that we were largely a nation of morons and gangsters." 13 Even films of high quality, from an American domestic standpoint, often registered a false impression abroad for lack of any general frame of reference by means of which the foreign audience could judge the normality of the type of situation presented. "While a film such as 'The Grapes of Wrath' may be generally hailed ... in the United States as an important social document, the effect of its showing abroad to audiences who have no understanding of the background or reasons for its production may well be a matter for serious considera-

12. Id. at 76-7.

13. Ibid. 
tion. Other films of the type of 'Tobacco Road', which offer a portrayal of the seamy side of American life leave definitely bad impressions." 14

But as with radio, war resulted in the discovery of new potentialities for the use of films. The War and Navy Departments discovered and made extensive use of instructional films through which the acquisition of skills was found to be greatly speeded up. Films like "Fighting Lady" and the British documentary "Desert Victory" showed how the war could be brought home to civilian audiences. Considerable experiments took place in the use of films to create helpful attitudes and a responsiveness to the needs of wartime. OPA films on food conservation, for example, proved their usefulness. The British film "Next of Kin" showed the dramatic possibilities of the use of films in preventing careless talk on military movements and activities. John Grierson in Canada created a completely new market for films bearing on the war. Progress was likewise made in the creation of understanding between nations. Films on South America prepared by OIAA, War Department films like "Know Your Ally Britain", and its British counterpart on the U.S., paved the way for the type of film which must now be produced in increasing quantities if international understanding is to grow.

Such growth is dependent on the satisfactory solution of two problems - the making of the right type of film for distribution and exchange between peoples and the finding of effective channels of distribution and exhibition for such pictures here and abroad. A number of factors at present balk progress on these fronts.

Here in America preoccupation with profits and the consequent concentration on entertainment films have resulted in a cautious and unadventurous attitude to the development of new fields of interest. As with our domestic radio, the public exposure to films outside a comparatively restricted field has been so limited as to retard, if not actually to negate, growth of wider interests. This freezing of the type of films presented to the public is aggravated by the powerful hold of the film producing companies, small in number but great in power, over the channels of distribution and the movie theatres of America. One result of this monopolistic hold has been a sad restriction of the market for documentary films and for films of independent producers. Equally restricted are the chances of foreign film producers to find an adequate market in America. Unless we open our markets to foreign films, we are unlikely to secure the removal of restrictions which at present obtain abroad on the import of our own films into foreign countries.

It is somewhat ironic that while we keep our own market virtually closed to foreign films, Hollywood has consistently sought government

14. Ibid. 
aid in removing restrictions on the acceptance of our films abroad. It is significant that the recent negotiations for a loan to France included provision for furthering the interests of Hollywood. As a result of this agreement, French film producers will have only thirty per cent of screening time in their own country as against the forty per cent they had before the war. The reason for Hollywood's concern with foreign markets is not hard to seek, and the facts merit examination.

American films have upwards of two-thirds of the world's markets. In some foreign markets the proportion is as high as ninety per cent. The industry's sales abroad are estimated at about $\$ 90,000,000$ annually. This figure constitutes thirty to forty per cent of the industry's gross revenue. We thus have a large and crucial investment in exported films. It is not unnatural, however, that such extensive control over foreign markets should arouse the apprehension of foreign governments. Questions both political and cultural here enter into the equation, as well as the concern of foreign governments to help their own domestic film industries. The Department of Commerce has listed fifty-eight legal restrictions affecting Hollywood's export business at the outset of the war. The French film quota has already been cited. The British quota obliges domestic film distributors to use twenty-five per cent British pictures during the year. To the political and cultural interests involved must be added an interest in revenue, now aggravated in foreign countries by severe shortages of exchange. What can be done to break down the barriers of international exchange and permit a healthier situation?

International agreement on the reduction of tariffs and quotas must obviously be sought. But the problem is more complex than that of Hollywood's preoccupation with unrestricted scope for profit. The import and export of films is merely part of the broader issue of international exchange. Where possible, we must offer some quid pro quo, as in the French loan, for what we seek. MIoreover, if Hollywood seeks the protection of government, it, too, must show some concern for the broader problems of international relations with which the State Department is concerned. "Managers of foreign or international departments believe they have the right to expect the aid of the American government on the sale of American pictures in foreign countries. The American picture, they point out, sells not only entertainment but a way of life. It has been called the greatest sale of American goods. For these reasons, the government has a direct stake in maintaining our foreign markets." 15 Such a claim on government, given the new world situation, involves reciprocal obligations on the part of the industry and a revised view of the American way of life which Hollywood deems it proper to export to other peoples.

15. Alicoat (ed.), Filu Dairy Year Book of Motion Pictures (1945). 
The exigencies of the postwar world, in other words, involve Hollywood in a wider conception of its responsibilities. Films for export must at least conform to minimal standards, both with respect to the offense that they may unconsciously give to foreign audiences and to the kind of impression of our way of life which they project. Selfregulation and self-education in this matter would seem to be the ideal course. Improvement might possibly be hastened through the creation of a government consultative committee, divested of any powers of censorship, before which previews of films for export could be exhibited. The danger of whitewashing America before the world, likely to result from an excessive concern for our good name by cautious civil servants, probably far outweighs the misapprehensions about us that may be created by such films as the "Grapes of Wrath" and "Tobacco Road." In the long run, what we need for understanding abroad is probably a far more candid and a far more comprehensive coverage of the many facets of our society and way of life. What we need most is a more adventurous, more imaginative, and more diverse treatment of subjects than has yet been realized in Hollywood.

Equally necessary is reciprocity on our part in reducing the direct and indirect controls over the import of foreign films into this country, which means, in turn, a breakdown of the control of our major film producers over the movie theatres through which films are distributed and shown.

These adjustments are not likely to be realized overnight. Our knowledge of the world abroad and others' knowledge of us is impeded not only by restrictions on the import and export of films but by the less than adult level of the pictures that are made. Hollywood, for all its efficiency, can hardly boast as yet that it is making, even indirectly through the medium of entertainment, any signal contribution to the problems of awareness and of understanding which face us today. The only hope (and it is a modest one) for any present advance is through increased production of documentary and informational films of the $16 \mathrm{~mm}$. variety. The number of such films is at present small. In their postwar plans for production of such films, countries like Great Britain have shown greater foresight than we have. Despite our wealth and know-how and despite the fillip of the war, we are not, even today, the leaders in this field. For $16 \mathrm{~mm}$. films, moreover, the crucial and as yet unresolved problem is that of distribution. Schools, clubs, and YMCA's are the present principal outlets. The number needs to be increased vastly, and educators need to be aroused to the as yet unrealized potentialities of films in education. If educators are prepared to take the long view, perhaps our greatest hope is in our schools where, both with respect to radio and the film, a range and standard of interests can be created which, in due course, will influence the trend of Hollywood productions. The industry has never been slow to respond 
to wide popular demand. It is only by raising the general standards of the public taste that we can hope to close the gap that now exists between the adolescent fare offered in movie houses and the adult demands on intelligence and awareness placed on us by the trend of world events.

The film is important not only because of its inherent and distinctive characteristics as a vehicle of thought and emotion but also by virtue of the huge and constant audiences it draws. It is estimated that in the United States the weelly film-going audience is over $S 0$ millions. In Britain, 25 millions (a figure proportionately as high as ours). In Russia there are some 18,000 motion picture theatres in about half of which admission is free. On the other hand, there are vast areas of the world in which other visual techniques must be substituted for lack of exhibition outlets for the film. In China, for instance, there are said to be only some 180 movie theatres for a population of 450 millions.

The scope for such alternative outlets was demonstrated in the war years. The use of the film strip, for instance, did wonders to spread information and understanding in a country where lack of communications left knowledge stagnant. It is said that in China, for instance, until quite late in the war the Flying Fortress was conceived of as a kind of impregnable captive balloon used for anti-aircraft purposes. In Chungking, "OWI, the British Ministry of Information and the Chinese Department of Education joined in serving 192 (filmstrip) centers reaching one million persons a month. As evidence of the versatility of the method, it may be added that the Soviet asked for negatives of seventy OWI filmstrips from which to prepare 500 prints of each, intended for the schools and covering such themes as American history, regional economy and the like." 16

The scope for the further use of filmstrips, particularly in education, remains largely to be explored. Like the film, it has distinctive uses and a particular relevance in such areas as China, where movie theatres and radio sets are few. Similar extensive use was made by OWII of picture exhibits. Traveling exhibits were organized, and the pictures were shown in centrally located glass cases. In successive months, audiences of more than a million persons were reached, one individual showing attracting an estimated 90,000 persons. Reconversion to peacetime has reduced the use of these techniques to negligible proportions, and as with respect to other media, we have to record a serious break in the projection of America throughout the world.

\section{Books and Magazines}

One other means of communication may be briefly referred to, namely, books and magazines. Here again, the backwardness of the

16. MacMaHon, op. cit. supra note 11, at 88 . 
United States in communicating itself abroad stands out in striking contrast to the energetic enterprise of other countries. "Hardly three per cent of the output of American book publishers has been exported. In contrast, about thirty per cent of British book production was being exported before the war." 17 The prewar export of books from Germany, particularly on scientific and technical subjects, was likewise tremendous. In 1941, the last year for which figures are availabe, export and re-export of books from Germany amounted to $\$ 35,000,000$, from Britain $\$ 16,000,000$, from Spain $\$ 10,000,000$, from France $\$ 9,000$,000 , from Switzerland $\$ 4,500,000$. Compare these figures with that for the United States which stood at a mere $\$ 800,000$. "American publishers for 57 years have permitted the objections, first of the Typesetters Union and latterly of the radio-broadcasting industry, to keep the United States almost alone among leading nations from adhering to the Berne Convention-with the result that American publishers have lost tangible tens of thousands of dollars through the wholesale pirating, notably by the Dutch and Chinese, of books entirely without legal protection outside the United States and its possessions, and with the further result that the United States has permitted the pirating of foreign authors-a circumstance which seriously dilutes American claims to morality and a respect for culture." 18

Such was our prewar record. Again the war provided an impetus which resulted in unprecedented developments. Through the Council on Books in Wartime, not only were over five million books a month delivered to the Army and Navy for use in the armed services, but a new publishing venture was undertaken to produce inexpensive books in translation or in English for use in liberated areas by the Overseas Branch of OWI. "Selected from a list of 40 American books, seventy editions were made in runs of 50,000 each: 21 in German, 22 in French, 5 in Italian and 22 in English." 19

A scheme of permanent export collaboration, undertaken in 1945 through the U. S. International Book Association, Inc., also was intended to facilitate the sale of American books abroad. With respect to all these activities, great difficulties still must be surmounted. Difficulties of shipping, high prices at the point of origin, uncontrolled prices at the point of destination, and confusion of tax and customs regulations in many countries are but examples. Our path is not made easier by the fact that we find ourselves in competition with government subsidized cartels, particularly in France, Spain, and Great Britain. "English publishers are using every means to secure closed markets and to engage their government in the furtherance of their

\footnotetext{
17. Id. at 89 .

18. WHITE AND LEIGH, op. cit. supra note 2, at 76.

19. MACMABON, op. cit. supra note 11 , at 92.
} 
interests. For every practical reason, their gorernment appears to be enthusiastically backing their efforts through the British Council and in many other ways. They have special paper quotas for export and Great Britain has shown in other instances a realization of the importance of books in determining the general English position outside the British Isles." 20

Here again, then, an urgent need for international agreement exists. The form of agreement proposed by the Commission on Freedom of the Press provides for ". . . an early and amicable settlement of the AngloAmerican rivalry, followed by an international copyright and reprint conference at which Britain and the United States would stand together for some formula designed to increase the flow of the books of all nations, ... effective means to curb pirating; the abolition of block sales, ... . and all other unfair competitive devices; establishment of the principle that any publisher has the right to place any.original product in any language on any bookstall in any country, subject only to the circumstances governing native publishers. . . ." 21

Similar international agreement is necessary with respect to magazines. The technological advances, referred to at the beginning of this study, now make possible huge circulations orerseas of the domestic editions of American magazines with a minimum time delay. Reader's Digest and Time magazine each have numerous editions abroad, the former with translated editions, the latter confining itself to English in its sixteen foreign editions. The phenomenal success of these publications has inevitably created resentment. Thus, a Brazilian publication was already complaining in $19 \pm 3$ with respect to the Portuguese edition of Reader's Digest that "sales are so large that on the days it comes out, the sales of most popular afternoon newspapers are prejudiced. It gives to readers in newsstands a relatively higher profit than offered by any other organ of our press." ${ }^{22}$ From Peru, likewise, came a report in 1944 that here there was "deep and growing resentment (especially in Argentina and Brazil) against United States publishing enterprises . . . which are considered in those countries as merely astute forms of 'cultural imperialism'." 23 Here again the future relations and interests of private enterprise and government are thrown into sharp focus. We are forced in the world today to reconsider the implications of laissez-faire. Industry in the communications field has new burdens of responsibility thrust upon it, and fresh concepts are called for as to the role of government in these explosive realms of ideas and of ideals.

20. Id. at 91.

21. WhITE AND LEIGH, op. cit. supra note 2, at 77-8.

22. MacNiaHon, op. cit. supra note 11, at 98-9.

23. Id. at 99. 


\section{The Role of the UnITEd Nations}

From this cursory study of the various media of communication now extensively in use or awaiting extensive exploitation, a few salient facts emerge clearly. (1) It would appear that the United States has been over-precipitate in its efforts at reconversion and has made dangerous sacrifices with respect to the means of continued projection of America throughout the world. We have allowed activities to lapse, the value of which cannot be challenged. (2) The enormous importance of communications from the point of view of our reputation abroad involves those engaged in the communication industries in new and delicate responsibilities. Difficult questions arise in every field as to the extent to which government should or should not move in on private industry (whether, as seems desirable in short-wave broadcasting, to take over the field or, as in films, to act in an advisory capacity on matters in which the national good name is involved). (3) Complex problems cry out for solution in regard to obstacles to the free flow of communications across national borders. (4) If we are to achieve, in time, an adult appreciation of the problems involved in the concept of one world, supplementary means must be found for the dissemination of information and ideas which private enterprise is either unwilling, unable or unfit to communicate. A vast expansion of educational material of the best sort and of the means for its dissemination is needed. These conclusions raise the question of the proper role of the United Nations and, more particularly, of UNESCO.

There is no dispute that these great international agencies warrant the support of every citizen in each of the participating countries. But the measure of their strength and prospects of success is the foresight and energy which we and other nations apply to this complex field of international communications. We may also face the danger of thrusting on these agencies a burden too great for them to carry. With respect. to the problems raised above, it would seem as if the Economic and Social Council of the United Nations might be a catalytic agency to precipitate the international agreements, earlier referred to in various contexts. From the United Nations, also, we might expect a modest but well organized flow of information through appropriate media carrying a message of its purpose and creating an awareness of its developing activities to the peoples of all participating nations. For the rest, the activities necessary for the increased and more fruitful flow of information between peoples would seem to devolve largely on UNESCO. One can only hope, however, that this agency will not be rushed into premature activity and dissipate its energies over too wide a field. A recent conference in this country, summoned to consider recommendations to the Preparatory Commission of UNESCO, envisaged for it services of information, production, evaluation, certification, distribution, utilization, research, and exchange of personnel. 
Each of these categories included a half dozen or more elaborate subheads of activity. The enthusiasm implicit in such proposals is greatly to be commended. But the desire for action and organization may prove no more than a convenient alibi for thought. Service in each of these categories is admittedly urgent and desirable. But there is as yet too little evidence that anyone has thought out and defined the real priorities of action to enable the flow of communications to irrigate but not inundate the seedling of international understanding. Before the technicians get to work on production, have we not certain fundamental questions to which no answer is yet forthcoming?

In the first place, perhaps we should examine with more care the validity of the contention in the preamble to UNNESCO's constitution about building the defenses of peace in the minds of men. There are those who believe that a free flow of information between peoples vill, of itself, bring about understanding and good will and therefore assurance of peace. A certain naiveté attaches to this point of view. It is certainly not proven. France and Germany, for instance, before the war knew one another better, as far as information goes, than perhaps we know any of our neighbors. But the free flow of information did not prevent war. A more mature consideration of this sanguine hope for peace may lead us to the conclusion that the primary task of UNESCO is a task of fundamental research-a world-wide study of ignorance and prejudice, its nature and its source. From such a study may emerge the knowledge to guide our selection of the subject areas for major emphasis in communications projects.

Another fallacy that may be concealed in UNESCO's definition of its major task is the assumption implicit in the phrase that peoples originate war. Is it not more accurate to say that peoples are drawn into war, and might not UNESCO examine with some care by whom the critical decisions which involve a nation in war are made and how peoples become involved in the decisions of a few? The origins of war are admittedly complex and stem in part at least from the history and aspirations of nations. Peace might be more secure if we had fuller knowledge of the science of comparative civilization. Here is another field of research which might be listed among the priorities on the agenda of UNESCO.

Combining the double thread of thought tentatively drawn in the preceding paragraphs-that peoples do not make wars and that a profounder knowledge of comparative civilization might modify the practice and decisions of those who do-another project suggests itself. Misunderstanding between statesmen and that nuclear group of governmental personnel associated with the formulation of national policies stems in part at least from a failure and incapacity to correlate our thinking with the thought pattern of nations whose history and civilization differ from our own. Seeing that the decisions leading to war are 
made, as it were, by an elite, should not UNESCO place emphasis on a more thorough training of such an elite in each and every country in the science of comparative civilization? We tend all too easily to project our own way of thinking on others. We may talk the same language, use the same terms, but these will have different connotations in different countries. If the officers of state and their associated civil servants in the field of international diplomacy were better grounded in such understanding, conflicts might be avoided. An example of a basic misunderstanding regarding the roots of national culture is our own naive assumption that democracy can be exported like commodities. Thus the whole concept of the re-education of Germany on democratic lines, to which we are now tragically committed, involves the patent fallacy that a term as complex as democracy can, as it were, be reduced to a formula and handed over to others as a blueprint from which to work. This is but one of many examples which suggests an intriguing line of study, namely, the extent to which our native genius in technology impairs the validity of our thinking when transferred to areas of thought and action where technological techniques and the habits of thought which these breed do not apply. It is such a transfer of thought which perhaps leads us to the over-optimistic conclusion that we can solve any problem. Our way of thinking perhaps precludes an understanding that problems of human relations are inherently complex and that some of them actually defy solution. There is no short-cut, no magic formula that will lead us to peace.

Where lack of information is concerned, the communication of the necessary knowledge, through films, over the air, and through publica. tions should be a relatively simple matter. But, as has been suggested, the mere spread of information provides no panacea. It may and should remove certain misunderstandings, the nature of which merit more searching inquiry. More information will certainly do much to destroy one of the potential germs of war, namely, that tendency in every nation to assume in varying degree its cultural superiority to that of others. When it comes to basic attitudes and to belief, to the mainsprings of aspiration and of action, a more complex question arises. With respect to films in particular, the "commissioning" of a picture in the sense of the predetermination of its content, approach to, and treatment of the subject according to some preconceived notion of social or international advantage, may prove a dangerous process. We here raise the whole question of the modern patron of the arts. The war years have accustomed us to a way of thinking on this subject which may need radical revision. The conscious creation of attitudes, which was the purpose of all wartime propaganda, may prove a dangerous recipe for the development of the film and other media of communication in peacetime. The patron of earlier days lent his favor to the artist. He did not commission him in the sense of predetermining the 
nature of his art. The modern patron, whether a government, a large business concern, or a rich man, tends to attach strings to his patronage of a kind which are all too often a denial of the artist's integrity. In our over-zealous concern to create good will among men, we run the risk of the production of stereotypes unconvincing in their appeals because they do not stem from the free spontaneous insight and creative urge of the individual artist. There is a school of thought today which seems to assume that the visual or verbal artist is merely a craftsman worling by formula, much like a bricklayer laying bricks from a blueprint. It may well be that understanding in its broadest and deepest sense will be enriched more by providing free scope for creative self-expression, with no strings attached, than by creating vast production factories in which the principles and practice of the conveyor-belt system are transferred to the realms of ideas and of ideals.

But if the artist is to be free, so must the audience for his creative work be free from all that at present hampers its responsiveness to real creative work and clouds or cheapens its sense of values. The mere expansion of the facilities for free communication is not necessarily a gain. Our American media of communication arecontrolled by powerful groups whose interests are commercial. In other countries the controls are those of government. In either case, the scope for and prospect of enlightenment, the chance for the liberation of men's sensibilities and awareness of reality from imposed stereotypes, depend on the extent to which real freedom for self-expression, individual and unconditional, is made possible. In this golden age of mass communication the task is in a sense harder, not easier, than ever before. Our capacity to reach mass audiences and to impose stereotypes involves the risk, if not the likelihood, of the enslavement rather than the libretion of men's minds. We have the example of Nazi Germany to prove this fact. But we delude ourselves if we suppose that because we, the champions of democracy, abhor the Nazi ideology, it cannot happen here. Just as dangerous, though in a very different sense, is the potential enslavement of men's minds resulting from the concentration of power in the manipulation of mass media where, as in our country, such manipulation is associated with the profit motive. The structure of our own communication media-press, radio and films-all evidence a progressive trend toward the concentration of power and, despite protestations to the contrary, the subordination of the product to the seeking of profits. From the point of view of national culture, such a concentration of power associated with such dominant motives bodes ill for us, unless controlled by a more mature sense of responsibility for what constitutes public interest.

This involves a fundamental reconsideration of our entire system of education. The vast expansion and exploitation of modern modia of communication are leading many to equate communication's golden 
age with the golden age of culture. The reverse may in fact be true. A little knowledge, even of a lot of things, is a dangerous thing. Communication "in depth," aimed at an understanding of other peoples that comprises all the subtleties and many-sided facets of their culture, even if this be achieved by the relatively few, may prove more fruitful of results than a more widespread dissemination of superficial information. The growth of communications tends to encourage a naive optimism as to its effects on peace. The achievement of peace is complex. Popular communication tends to obscure this inherent complexity in every situation. There are limits to what can be simplified. Simpletons will not save the world. We might do well, indeed, to ponder in this modern age of miracles the thought of one who more than eighty years ago attempted to evaluate the growing impact in his time of the printed word alone. "In former times almost every body who could was accustomed to contribute in an active way to the formation of opinion. Men evolved their own political ideas and drew forth the ideas of their friends by keen oral discussion. . . . But gradually. . . . What had been an intellectual exercise practiced in a random way by thousands, was turned into a branch of industry, and pursued with great skill by a few. . . . At length the principle of divided labor became so complete in its application to the forming of political opinions, that by glancing at a newspaper, and giving swift assent to its assertions and arguments, many a man was ... dispensed from the necessity of having to work his own way to a conclusion.

But to spare a man from a healthy toil is not always an unmixed good. To save a free-born citizen from the trouble of thinking upon questions of State is to take from him his share of dominion; and, although it be true that he who follows printed advice is under a guidance more skillful and dexterous than any he could have got from his own untutored mind, he is less of a man and, upon the whole, is less fair, less righteous than one who in a ruder fashion contrives to think for himself. . . . The blessing conferred by print will perhaps be complete when the diligence, the wariness and, above all, the courageous justice of those who read, shall be brought into fair proportion with the skill and the power of those who address them." 24

24. 1 Kinglake, The Invasion of the Crimea (1863) 358-60. 